\title{
PENGARUH SUPERVISI DAN KOMPETENSI MELALUI DISIPLIN KERJA TERHADAP KINERJA GURU MAN SE-KOTA MEDAN
}

\author{
Ellya Hafni \\ Magister Manajemen Pendidikan Tinggi , Pascasarjana \\ Universitas Muhammadiyah Sumatera Utara, Medan, Sumatera Utara, Indonesia \\ Elyyahafnisiregar@gmail.com
}

\begin{abstract}
Abstrak
Pendidikan merupakan bagian penting dalam kehidupan manusia, dimana manusia dapat membina kepribadiannya dengan mengembangkan potensi yang dimiliki sesuai dengan nilai-nilai yang ada di dalam masyarakat. Penelitian ini bertujuan untuk mengetahui pengaruh supervisi kepala madrasah dan kompetensi diri terhadap kinerja guru dan disiplin kerja guru MAN se-Kota Medan. Penelitian ini dilakukan di Madrasah Aliyah Negeri (MAN) Se-Kota Medan, tepatnya di MAN 1 Medan dengan alamat jalan Williem Iskandar No.7b Kelurahan Sidorejo Kecamatan Medan Tembung, MAN 2 Model Medan dengan alamat jalan Williem Iskandar No.7a Kelurahan Sidorejo Kecamatan Medan Tembung dan MAN 3 Medan dengan alamat Jalan Pertahanan Patumbak No. 99 Sigara-gara Patumbak. Pelaksanaan penelitian ini pada bulan Januari - Februari 2019. Adapun penelitian ini merupakan jenis penelitian kuantitatif dengan jumlah populasi sebanyak 162 orang dan teknik pengambilan sampel dilakukan dengan teknik totally sampling. Hasil penelitian pada pengujian menunjukkan bahwa, terdapat pengaruh yang positi dan signifikan antara supervisi kepala sekolah terhadap kompetensi guru yakni sebesar 0,305, terdapat pengaruh yang positi dan signifikan antara supervisi secara langsung terhadap kinerja guru sebesar 0,186, terdapat pengaruh yang positi dan signifikan antara disiplin kerja terhadap kinerja guru MAN Se-Kota Medan yakni 0,125 atau 12,5\%, terdapat pengaruh positif dan signiikan antara disiplin kerja secara langsung terhadap kompetensi diri sebesar 0,226 , dan terdapat pengaruh yang positif dan signifikan antara kompetensi guru terhadapkinerja guru yakni 0,341 atausebesar 34,1\%.
\end{abstract}

Kata Kunci : Supervisi, Kompetensi guru, Disiplin Kerja Guru, Kinerja Guru

\section{PENDAHULUAN}

Pendidikan merupakan bagian penting dalam kehidupan manusia, dimana manusia dapat membina kepribadiannya dengan jalan mengembangkan potensi-potensi yang dimiliki sesuai dengan nilainilai yang ada di dalam masyarakat. Dengan demikian dari nilai-nilai yang ada berlangsung suatu proses yang selaras dengan tujuan utama pendidikan yaitu mengembangkan kemampuan, pengetahuan, ketrampilan dan sikap anak didik secara optimal. Proses pendidikan sangat menentukan kepribadian, skill serta budi pekerti manusia tersebut.

Madrasah sebagai lembaga penanggungjawab dan penyelenggara pendidikan mempunyai peran penting dalam memberikan pelayanan kepada masyarakat dalam menciptakan sumber daya manusia yang baik. Hal ini menjadikan fungsi dan tugas madrasah semakin hari semakin berat seiring dengan meningkatnya keinginan masyarakat untuk mendapatkan pelayanan pendidikan yang lebih baik. Peningkatan mutu pelayanan dapat dilihat dari kinerja tenaga kependidikan (guru) di suatu madrasah sebagai potret depan dalam proses pembelajaran.

Peraturan Menteri Pendayagunaan Aparatur Negara dan Reformasi Nomor 16 Tahun 2009 tentang Jabatan Fungsional Guru dan Angka Kreditnya Pasal 5 Ayat 1 menjelaskan bahwa tugas utama Guru adalah mendidik, mengajar, membimbing, mengarahkan, melatih, menilai, dan mengevaluasi peserta didik pada pendidikan anak usia dini jalur pendidikan formal, pendidikan dasar, dan pendidikan menengah serta tugas tambahan yang relevan dengan fungsi madrasah/madrasah.

Namun sampai saat ini, kinerja mengajar guru di Indonesia masih belum mencapai pada taraf yang memuaskan walaupun berbagai program telah pemerintah gulirkan. Hal ini dapat dilihat dari data Bappenas menyebutkan bahwa hasil survey yang dilakukan oleh UNESCO untuk kualitas kinerja guru di Indonesia berada pada level 14 dari 14 negara berkembang $^{[1]}$. Hal ini menunjukkan bahwa kinerja mengajar guru di Indonesia masih belum sesuai dengan yang dicita-citakan. Dengan kata lain, sebagian guru di Negara kita belum optimal melaksanakan kinerja mengajarnya sesuai dengan yang diharapkan.

Banyak faktor yang mempengaruhi kinerja mengajar guru, salah satu faktor ekstrinsik yang berkontribusi secara signifikan terhadap prestasi, dan profesionalisme guru ialah layanan supervisi kepala madrasah. Supervisi kepala madrasah sangatlah penting untuk memperbaiki dan meningkatkan kinerja mengajar guru. Seorang kepala madrasah harus benar-benar memahami dan melaksanakan fungsi supervisi dengan benar dan tepat di madrasah yang dia pimpin. Sebagai pemimpin, ia harus mengetahui, memahami semua hal yang berkaitan dengan administrasi madrasah dan potensi yang dimiliki oleh para gurunya, sehingga komunikasi dengan guru dan karyawan madrasah akan membantu kinerjanya, terutama untuk menyelesaikan masalah yang dihadapi oleh madrasah yang dipimpinnya ${ }^{[2]}$ maka supervisi perlu dilakukan di setiap madrasah. 
Dalam melakukan supervisi yang berperan penting adalah kepala madrasah. Kepala madrasah sebagai supervisor mempunyai peran yang besar dalam keberhasilan lembaga pendidikan. Sebagai seorang supervisor mempunyai tanggung jawab untuk meningkatkan kemampuan guru dalam mengelola kegiatan pembelajaran di madrasah serta mempunyai peranan yang sangat penting terhadap perkembangan dan kemajuan madrasah. Oleh karena itu, kepala madrasah harus melakukan supervisi.

Selain supervisi, kinerja guru juga dipengaruhi oleh kompetensi guru, hal ini terdapat dalam Depdiknas yang menyatakan bahwa kompetensi guru juga mempengaruhi kinerja guru, sebab kompetensi guru pada hakikatnya berupa spesifikasi dari pengetahuan dari pengetahuan, keterampilan dan sikap yang dimiliki seseorang serta penerapannya di dalam pekerjaan. Kompetensi guru diartikan sebagai seperangkat pengetahuan, keterampilan dan perilaku yang harus dimiliki, dihayati, dan dikuasai oleh guru dalam melaksanakan tugas keprofesionalannya. Guru dituntut untuk dapat mengembangkan kemampuannya sesuai standar. Tuntutan akan kemampuan guru inilah yang mengharuskan berbagai upaya konkrit untuk meningkatkan profesionalisme guru.

Jika dilihat dari beberapa penelitian yang terkait dengan kompetensi guru, menunjukkan adanya pengaruh kompetensi guru terhadap hasil belajar siswa $^{[3]}$. Kompetensi guru meliputi; kompetensi pedagogik, kompetensi kepribadian, kompetensi sosial, dan kompetensi profesional yang diperoleh melalui pendidikan profesi, pelatihan, dan pengalaman profesional. Dari keempat kompetensi tersebut, kompetensi pedagogik merupakan kompetensi yang berperan sangat penting bagi guru dalam melaksanakan proses pembelajaran.

Kompetensi pedagogik merupakan kompetensi utama yang harus dimiliki guru agar pembelajaran yang dilaksanakan berlangsung secara efektif dan dinamis. kompetensi pedagogik merupakan kompetensi yang menuntut guru untuk dapat mengelola pembelajaran bagi peserta didiknya, agar tercipta pembelajaran yang menarik. Sering sekali seorang guru mengartikan kompetensi pedagogik hanya sebatas kemampuan mengajar untuk menyampaikan ilmu pengetahuan, tanpa mengetahui apa itu kompetensi pedagogik yang sesungguhnya. Jadi, kesadaran guru tentang hal tersebut sangat dibutuhkan, mengingat tugasnya bukan hanya menyampaikan pembelajaran saja, tetapi juga sebagai pengembang potensi yang dimiliki peserta didik.

Untuk melaksanakan peningkatkan kinerja, kedisiplinan, kesadaran untuk melaksanakan tugas, ketepatan dalam melaksanakan tugas, dan ketaatan guru dalam melaksanakan tugas juga berperan dalam meningkatkan kinerja guru.

Berdasarkan hasil wawancara terhadap beberapa guru Madrasah Aliyah Negeri (MAN) se-Kota Medan, diperoleh informasi bahwa kebanyakan guru masih takut terhadap supervisi, hal ini karena mereka berpikir bahwa supervisi adalah ajang untuk mencari kesalahan dan kekurangan mereka. Guru mulai mempersiapkan diri untuk melengkapi perangkat pembelajaran, mempersiapkan media dan model pembelajaran hanya ketika akan dilakukan supervisi.

Berdasarkan hasil observasi peneliti, menyimpulkan bahwa kinerja dari para guru MAN se-Kota Medan diduga masih belum optimal. Dugaan ini muncul karena ada indikasi-indikasi yang bisa menurunkan kinerja guru, diantaranya masih ada guru yang belum melaporkan atau bahkan menyusun perangkat pembelajaran seperti prota, promes, RPP dan sebagainya yang berkaitan dengan kompetensi pedagogik guru. Selain itu, dari hal kedisiplinan, masih terdapat juga guru yang datang terlambat untuk masuk madrasah ataupun kelas untuk mengajar.Ini dimungkinkan kurangnya kesadaran guru dalam berdisiplin dalam bekerja yang dimiliki oleh para guru. Jika hal ini dibiarkan berlanjut tanpa adanya teguran baik secara langsung maupun tidak langsung maka akan mempengaruhi kinerja guru tersebut.

Berdasarkan uraian dan hasil penelitian sebelumnya di atas patut diduga bahwa terdapat hubungan antara supervisi, kompetensi guru dan disiplin kerja dengan kinerja guru.maka penulis tertarik untuk melakukan penelitian lebih lanjut mengenai kinerja guru dengan judul "Pengaruh Supervisi Dan Kompetensi Melalui Displin Kerja Terhadap Kinerja Guru Di MAN se- Kota Medan".

\section{Rumusan Masalah}

Berdasarkan masalah yang dijadikan fokus penelitian, masalah pokok penelitian tersebut dirumuskan sebagai berikut :

1. Apakah terdapat pengaruh yang positif supervisi kepala madrasah terhadap kinerja guru MAN seKota Medan?

2. Apakah terdapat pengaruhyang positif kompetensi diri terhadap kinerja guru MAN seKota Medan?

3. Apakah terdapat pengaruh yang positif supervisi dan kompetesi diri terhadap kinerja guru MAN se-Kota Medan?

4. Apakah terdapat pengaruh yang positif supervisi, kompetensi dan disiplin kerja terhadap kinerja guru MAN se-Kota Medan?

\section{Tujuan Penelitian}

Penelitian ini bertujuan untuk mengetahui:

1. Bagaimana pengaruh supervisi kepala madrasah terhadap kinerja guru MAN se-Kota Medan.

2. Bagaimana pengaruh kompetensi diri terhadap kinerja guru MAN se-Kota Medan.

3. Bagaimana pengaruh supervisi dan kompetesi diri terhadap kinerja guru MAN se-Kota Medan. 
4. Bagaimana pengaruh supervisi, kompetensi dan disiplin kerja terhadap kinerja guru MAN seKota Medan.

\section{Manfaat Penelitian}

Hasil penelitian ini diharapkan mempunyai banyak manfaat, yaitu :

1. Manfaat Teoritis

Diharapkan dapat menambah wawasan pengetahuan dibidang pendidikan terutama tentang supervisi kepala madrasah, displin kerja dan kinerja guru serta hubungan supervisi kepala madrasah dan disiplin kerja terhadap kinerja guru MAN. Sebagai bahan acuan dan bahan pertimbangan bagi penelitian yang sejenis.

2. Manfaat Praktis

Penelitian ini diharapkan dapat memberikan masukan kepada madrasah mengenai hubungan supervisi kepala madrasah dan disiplin kerja terhadap kinerja guru yang ada dimadrasah tersebut.

\section{Kajian Pustaka}

\section{Kinerja Guru}

Kinerja guru adalah kemampuan dan usaha guru untuk melaksanakan tugas pembelajaran sebaikbaiknya dalam perencanaan program pengajaran, pelaksanaan kegiatan pembelajaran dan evaluasi hasil pembelajran berarti sesuatu yang dicapai, prestasi yang diperlihatkan atau kemampuan kerja. Kinerja guru berkaitan dengan kompetensi guru, artinya agar memilki kinerja yang baik seorang guru harus didukung dengan kompetensi yang baik. Jika seorang guru tidak memiliki kompetensi yang baik maka tidak akan mungkin memiliki kinerja yang baik.

Manfaat penilaian kinerja guru bagi sekolah antara lain (1)Penyesuaian-penyesuaian kompensasi personel sekolah, (2)Perbaikan kinerja personel sekolah, (3)Kebutuhan latihan dan pengembangan sekolah, (4)Pengambilan keputusan dalam hal penempatan, promosi, mutasi, pemecatan, pemberhentian, dan perencanaan personel sekolah, (5)Penelitian personel sekolah, (6)Membantu diagnosis terhadap kesalahan desain personel sekolah $^{[4]}$.

Keberadaan guru dalam melaksanakan tugas dan kewajibannya dipengaruhi oleh dua faktor yakni (1)Faktor Internal Kerja Guru. Faktor internal kerja guru adalah faktor yang datang dari dalam diri guru yang dapat mempengaruhi, contohnya ialah kemampuan, keterampilan, kepribadian, persepsi, motivasi menjadi guru, pengalaman lapangan, dan latar belakang keluarga. (2)Faktor eksternal kinerja guru. Faktor eksternal kinerja guru adalah faktor yang datang dari luar yang dapat mempengaruhi kinerjanya, contohnya ialah gaji, sarana-prasarana, lingkungan kerja fisik, dan kepemimpinan.

Berdasarkan pendapat yang di sampaikan, dapat disimpulkan bahwa kedua faktor dapat mempengaruhi baik buruknya kinerja pegawai. Jika kedua faktor selalu di perhatikan dan di tingkatkan di harapkan dapat berpengaruh baik terhadap peningkatan kinerja guru.

Penilaian kinerja guru merupakan acuan bagi sekolah/madrasah untuk menetapkan pengembangan karier dan promosi guru. Bagi guru sendiri, penilaian kinerja guru merupakan pedoman untuk mengetahui unsur-unsur kinerja yang dinilai. Selain itu, juga sebagai sarana untuk mengkaji kelebihan dan kekurangan guru tersebut dalam rangka memperbaiki kualitas kinerjanya. Penilaian kinerja guru dilakukan terhadap kompetensi guru sesuai dengan tugas pembelajaran, pembimbingan, atau tugas tambahan yang relevan dengan fungsi sekolah/madrasah.

\section{Supervisi Pendidikan}

Istilah supervisi telah cukup lama dikenal dan tidak asing di telinga dunia pendidikan. Dalam dunia pendidikan supervisi sering diidentikkan dengan pengawasan, memang hal ini dapat dimaklumi bila dikaji dari sisi etimologis. Supervisi secara etimologis berasal dari kata "super" dan "visi" yang mengandung arti melihat dan meninjau dari atas atau menilik dan menilai dari atas yang dilakukan oleh pihak atasan terhadap aktivitas, kreativitas, dan kinerja bawahan ${ }^{[5]}$

Dari berbagai pendapat para ahli di atas dapat di tarik sebuah pengertian bahwa yang dimaksud dengan supervisi adalah bimbingan profesional yang diberikan oleh atasan/kepala madrasah yang merupakan orang yang memiliki pengetahuan dan keterampilan yang lebih kepada bawahannya untuk membantu dalam pengembangan situasi belajarmengajar agar tercipta lingkungan pembelajaran yang efektif.

Ditinjau dari objek yang di supervisi, ada tiga macam supervisi yaitu (1)Supervisi Akademik Yaitu yang menitik beratkan pengamatan supervisor pada masalah-masalah akademik, yaitu hal-hal yang langsung berada dalam lingkungan kegiatan pembelajaran pada waktu siswa sedang dalam proses pembelajaran, (2)Supervisi Administrasi yang menitik beratkan pengamatan supervisor pada aspekaspek administrasi yang berfungsi sebagai pendukung dengan pelancar terlaksanannya pembelajaran. (3)Supervisi Lembaga yang menitik beratkan pengamatan supervisor pada aspek-aspek yang berada di sentral madrasah. Jika supervisi akademik dimaksudkan untuk meningkatkan pembelajaran, maka supervisi lembaga dimaksudkan untuk meningkatkan nama baik madrasah atau kinerja $\operatorname{madrasah}^{[6]}$.

Secara umum supervisi memiliki kegunaan untuk memberikan bantuan dalam mengembangkan situasi 
belajar mengajar yang lebih baik, melalui usaha peningkatan profesional mengajar; menilai kemampuan guru sebagai pendidik dan pengajar dalam bidang masing-masing guna membantu mereka melakukan perbaikan dan jika diperlukan dengan menunjukkan kekurangan-kekurangan untuk diperbaiki sendiri supervisi bertujuan sebagai berikut (1)Memperbaiki proses belajar mengajar (2)Perbaikan tersebut dilaksanakan melalui supervisi professional, (3)Yang melakukan supervisi adalah supervisor, (4)Sasaran supervisi tersebut adalah guru atau orang lain yang ada kaitannyaatau dalam rangka memberikan layanan supervisi kepada guru, (5)Secara jangka panjang maksud supervisi tersebut adalah memberikan kontribusi bagi pencapaian tujuan pendidikan.

\section{Kompetensi Guru}

Adapun macam-macam kompetensi yang harus dimiliki oleh tenaga guru antara lain: kompetensi pedagogik, kepribadian, profesional dan sosial yang diperoleh melalui pendidikan profesi. Keempat kompetensi tersebut terintegrasi dalam kinerja guru.

Dalam pembahasan kompetensi guru hanya dibatasi pada kompetensi pedagogik. Penelitian ini bermaksud mengungkapkan dan menonjolkan kompetensi pedagogic secara khusus serta berusaha meninjau lebih dalam mengenai kompetensi pedagogik $^{[7]}$

Kompetensi pedagogik adalah kemampuan mengelola pembelajaran siswa yang meliputi pemahaman terhadap siswa, perancangan dan pelaksanaan pembelajaran, evaluasi hasil belajar, dan pengembangan siswa untuk mengaktualisasikan berbagai potensi yangdimiliki. Kompetensi paedagogik mengharuskan guru memiliki jiwa pendidik mendarah daging. Artinya, nilai-nilai pendidikan tidak sekedar dihafal secara teoritis, tetapi telah menjadi bagian dari perilaku dirinya. Kompetensi paedagogik meliputi pemahaman wawasan/landasan terhadap kependidikan, siswa, kurikulum, perancangan pembelajaran yang dialogis dan mendidik, pelaksanaan pembelajaran, sampai kepada pengembangan siswa untuk mengaktualisasikan potensi-potensi yang dimilikinya $^{[8]}$

Sebagai salah satu jenis profesi, guru memiliki kompetensi-kompetensi tertentu yang harus dipenuhi. Adanya kompetensi tersebut memiliki posisi yang penting dalam profesi keguruan. Berikut manfaat kompetensi guru (1)Kompetensi Guru sebagai Alat Seleksi Penerimaan Guru, (2)Kompetensi Guru Penting dalam Rangka Pembinaan Guru, (3)Kompetensi Guru Penting dalam Rangka Penyusunan Kurikulum, (4)Kompetensi Guru Penting dalam Hubungan dengan Kegiatan dan Hasil Belajar Siswa $^{[9]}$

\section{Disiplin Kerja Guru}

Disiplin adalah suatu kondisi yang tercipta dan terbentuk melalui proses dari serangkaian perilaku yang menunjukkan nilai-nilai ketaatan, kesetiaan, keteraturan dan atau ketertiban, karena nilai-nilai itu sudah membantu dalam diri individu tersebut, maka sikap atau perbuatan yang dilakukan bukan lagi dirasakan sebagai beban, sebaliknya akan menjadi beban bila tidak berbuat sesuatu yang telah ditetapkan.

Sementara itu guru adalah suatu profesi yang artinya suatu jabatan atau pekerjaan yang memerlukan keahlian khusus sebagai guru. Jenis pekerjaan ini mestinya tidak dilakukan oleh sembarangan orang diluar bidang kependidikan ${ }^{[10]}$. Dengan demikian jelaslah bahwa guru merupakan suatu profesi yang tugasnya adalah mengajar, membimbing dan mengarahkan siswanya agar dapat belajar dengan baik dan kreatif sehingga tujuan pembelajaran dapat tercapai sesuai dengan standar yang ditetapkan.

Jadi disiplin guru adalah suatu kondisi tertib dan teratur yang dimiliki oleh guru dalam melaksanakan tugasnya di madrasah, tanpa ada pelanggaran yang merugikan terhadap peserta didik sendiri maupun terhadap sekolah secara keseluruhan ${ }^{[11]}$. Guru memiliki pengaruh yang cukup besar terhadap proses pembelajaran dan perilaku para siswanya. Jika para guru dapat bersikap disiplin terhadap tata tertib yang ada di sekolah, maka cenderung para siswa pun akan meniru sikap disiplin para gurunya tersebut.

Disiplin kerja guru akan berfungsi apabila guru memiliki aspek-aspek sebagai berikut 1)Hadir dan pulang tepat waktu, 2)Menandatangani daftar hadir, 3)Membuat program dan persiapan sebelum mengajar, 4)Melaksanakan tugas dan tanggung jawab, 5)Melaksanakan penilaian terhadap pelaksanaan KBM, 6)Menyelesaikan administrasi kelas dan sekolah secara baik dan teratur 7)Memelihara dan menciptakan lingkungan kerja dan belajar yang menyenangkan ${ }^{[12]}$

\section{Kerangka Teoritik}

Pengaruh Supervisi, kompetensi diri, dan disiplin kerja terhadap kinerja guru dapat digambarkan dalam kerangka pemikiran sebagai berikut:

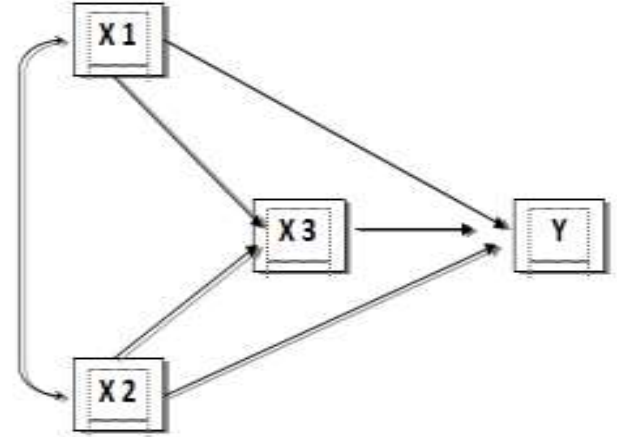

Gambar 2.1. Teknik analisis jalur penelitian 


$$
\begin{aligned}
& \text { Keterangan: } \\
& \mathrm{X} 1=\text { Supervisi } \\
& \mathrm{X} 2=\text { Kompetensi diri } \\
& \mathrm{X} 3=\text { Disiplin kerja } \\
& \mathrm{Y}=\text { Kinerja guru }
\end{aligned}
$$

\section{METODE PENELITIAN}

Metode pada penelitian ini adalah deskriptif asosiatif dan pengumpulan data pada penelitian dengan teknik angket, observasi dan dokumentasi. Teknik angket digunakan untuk memperoleh data pengukuran pada variabel supervisi, kompetensi diri dan disiplin kerja yang merupakan variabel independen. Sedangkan teknik observasi digunakan pada variabel kinerja guru yang merupakan variabel dependen

Adapun pengambilan sampel dalam penelitian ini, dilakukan dengan teknik Pengambilan Sampel Total, dimana seluruh populasi yang ada digunakan sebagai sampel penelitian, sehingga sampel dalam penelitian ini berjumlah 162 orang.

Dalam penelitian kuantitatif, teknik analisis data yang digunakan sudah jelas, dan diarahkan untuk menjawab rumusan masalah atau menguji hipotesis yang telah dirumusan. Dalam rangka menguji hipotesis dalam penelitian ini dilakukan beberapa analisis antara lain yaitu (1) uji klasik atau uji prasyarat, dimana uji prasyarat pada penelitian ini menggunakan uji normalitas dengan uji Kolmogorov-smirnov, uji multikolinearitas, dan uji heterokedastisitas. (2) Uji analisis yaitu menggunakan uji regresi linear Berganda atau uji statistik $\mathrm{F}$ dimana pengujian ini dilakukan untuk menguji pengaruh variabel $\mathrm{X}_{1}, \mathrm{X}_{2}$, Dan $\mathrm{X}_{3}$ secara bersama-sama terhadap $Y$. Selain itu menggunakan uji regresi sederhana atau uji $t$ dilakukan untuk menguji antar variabel

\section{HASIL DAN PEMBAHASAN}

\section{Uji Prasyarat Analisis Data}

Hasil pengujian normalitas data dengan uji kolmogorof-Smirnov Test, menunjukan nilai Asymp. Sig (2-tailed) untuk variabel sistem pengukuran kinerja secara diagnostik, sistem pengukuran kinerja secara interaktif, sikap terhadap resiko, kuantitas pembiayaan, dan kualitas proses pembiayaan, lebih besar dari 0,06. Hal ini menunjukan seluruh variabel

\begin{tabular}{|c|c|c|c|c|c|}
\hline & & \begin{tabular}{|l|} 
Kinerja Guru \\
\end{tabular} & Supervisi & Disiplin Kerja & Kompetensi \\
\hline $\bar{N}$ & & 102 & 162 & 162 & 162 \\
\hline \multirow{2}{*}{$\begin{array}{l}\text { Nomad } \\
\text { Paramelers' }\end{array}$} & Mean & 141,73 & 14393 & 146.94 & 14269 \\
\hline & Stad Deriebion & 11.824 & 10.834 & 11.092 & 12519 \\
\hline \multirow{3}{*}{$\begin{array}{l}\text { UlostExtreme } \\
\text { Differerces }\end{array}$} & Absolute & 104 & 090 & .061 & 089 \\
\hline & Postive & .074 & 1090 & .061 & 089 \\
\hline & Negative & -104 & -076 & -058 & -086 \\
\hline \multicolumn{2}{|c|}{ Koinogyor-Sminoiz } & 1328 & 1.143 & .777 & 1.131 \\
\hline \multicolumn{2}{|c|}{ Asymo. Sig (2taied) } & .053 & 146 & .583 & .155 \\
\hline
\end{tabular}
terdistribusi secara normal. Hasil dari pengujian normalitas disajikan pada tabel 4.4 sebagai berikut.

Tabel 3.1 Uji Normalitas One-Sample Kolmogorov-Smirnov Test a. Testostibstisnis Normal.

Hasil uji normalitas bahwa nilai Asymp. Sig (2tailed) $>\alpha$. Sehingga dari hasil Kolmogorov-Smirnov di atas maka untuk $\mathrm{Y}=0,059$ yang artinya $>0,05$ maka populasi berdistribusi normal, $\mathrm{X}_{1}=0,146$ yang artinya $>0,05$ maka populasi berdistribusi normal, $\mathrm{X}_{2}$ $=0,583$ yang artinya $>0,05$ maka populasi berdistribusi normal, dan $\mathrm{X}_{3}=0,155$ yang artinya > 0,05 maka populasi berdistribusi normal. Dapat disimpulkan bahwa data supervisi $\left(\mathrm{X}_{1}\right)$, disiplin kerja $\left(\mathrm{X}_{2}\right)$, dan kompetensi guru $\left(\mathrm{X}_{3}\right)$ serta kinerja guru $(\mathrm{Y})$ adalah berdistribusi normal. Dengan demikian data penelitian ini secara statistic memenuhi kriteria normal dan dapat dilakukan analisis lebih lanjut.

\section{Uji Linieritas}

Untuk mengetahui bentuk hubungan antara variabel eksogenus dengan variabel endogenus bersifat linier atau tidak digunakan uji linieritas dengan uji F. Hipotesis yang diajukan dalam uji linieritas adalah:

\section{Ho: regresi tidak linier}

Ha: regresi linier

Kriteria pengujian: Tolak Ho jika signifikansi Fhitung> 0,05 atau Terima Ho jika signifikansi

\begin{tabular}{|c|c|c|c|c|}
\hline \multirow{2}{*}{$\Sigma_{0}$} & \multirow{2}{*}{$\begin{array}{c}\text { Tariabel Eksogen } \\
\text { terhadap } \\
\text { Variabel } \\
\text { Easogen }\end{array}$} & \multicolumn{3}{|c|}{ cjlinieritas } \\
\hline & & $\mathrm{F}_{\mathrm{i}}$ & Sig. & Status \\
\hline 1 & $X_{1}$ dengan $Y$ & 5,369 & 0.223 & Lirier \\
\hline 2 & $X_{1}$ dengan $X_{s}$ & 3,513 & 0,179 & Linier \\
\hline 3 & $\mathrm{X}_{\mathrm{I}}$ dengan $\mathrm{Y}$ & 3,8002 & 0.165 & Linier \\
\hline 4 & $X_{2}$ dengan $X_{1}$ & 2,564 & 0,072 & Linier \\
\hline 5 & $\mathrm{X}_{9}$ dengan $\mathrm{Y}$ & 2,596 & 0,082 & Liniar \\
\hline
\end{tabular}
Fhitung $\leq 0,05$. Kriteria pengujian: tolak Ho, jika signifikansi Fhitung< 0,05 atau terima Ho jika signifikansi Fhitung $\geq 0,05$.

Tabel 3.2 Rangkuman Hasil Uji Linieritas

\section{Keterangan:}

$$
\begin{aligned}
& \mathrm{X}_{1}=\text { Supervisi Kepala Sekolah } \\
& \mathrm{X}_{2}=\text { Disiplin Kerja } \\
& \mathrm{X}_{3}=\text { Kompetensi Diri } \\
& \mathrm{Y}=\text { Kinerja Guru }
\end{aligned}
$$

Dapat dilihat bahwa hasil perhitungan uji linieritas dengan Deviation from Linearity diperoleh semua nilai signifikansi lebih besar(sig) > 0,05. Berdasarkan hasil analisis tersebut dapat disimpulkan bahwa semua bentuk regresi adalah linier dan berarti pada $\alpha$ sebesar 0,05 . 


\section{Uji Autokorelasi}

Hasil uji autokorasi menggunakan Durbin Watson (DW-Test) untuk setiap model regresi dalam penelitian ini sebagai berikut:

1. Uji Autokorelasi sub struktur $-1: X_{3}=\rho \times 3 \times 1$ $\mathrm{X}_{1}+\rho \times 3 \times 2 \mathrm{X}_{2}+\varepsilon 1$

Berdasarkan hasil perhitungan diketahui bahwa DW-hitung $=2,313$ dibandingkan dengan nilai tabel pada signifikan 0,05 dengan $\mathrm{n}=162$, jumlah variabel independen atau $\mathrm{k}=2$, $\mathrm{dL}$ $=1,73064$ dan $\mathrm{dU}=1,75546$. Berdasarkan nilai ini maka DW hitung $=2,131$ lebih besar dari batas atas $\mathrm{dU}=1,75546$ dan kurang dari $(4-$ $\mathrm{dU})=4-1,75546=2,24454$, atau 1,73046 < $2,131<2,24454$ maka dapat disimpulkan bahwa tidak terdapat autokorelasi.

2. Uji Autokorelasi sub struktur $-2: \mathrm{Y}=\rho \mathrm{yx} 1 \mathrm{X}_{1}$ $+\rho \mathrm{yx} 2 \mathrm{X}_{2}+\rho \mathrm{x} 4 \mathrm{x} 2 \mathrm{X}_{2}+\varepsilon 2$

Berdasarkan hasil perhitungan diketahui bahwa DW-hitung $=2,031$ dibandingkan dengan nilai tabel pada signifikan 0,05 dengan $\mathrm{n}=162$, jumlah variabel independen atau $\mathrm{k}=3$, $\mathrm{dL}$ $=1,71815$ dan $\mathrm{dU}=1,76810$. Berdasarkan nilai ini maka DW hitung $=2,031$ lebih besar dari batas atas $\mathrm{dU}=1,76810$ dan kurang dari $(4-$ $\mathrm{dU})=4-1,76810=2,2319$, atau $1,71815<$ $2,031<2,2319$ maka dapat disimpulkan bahwa tidak terdapat autokorelasi.

\section{Pengujian Hipotesis}

Pengujian hipotesis untuk setiap model sub struktur penelitian dengan menggunakan alat bantu komputer aplikasi program SPSS for Windows versi 16. Berdasarkan tahapan analisis perhitungan di atas, maka rumusan dan hipotesis penelitian sebagai berikut ini:

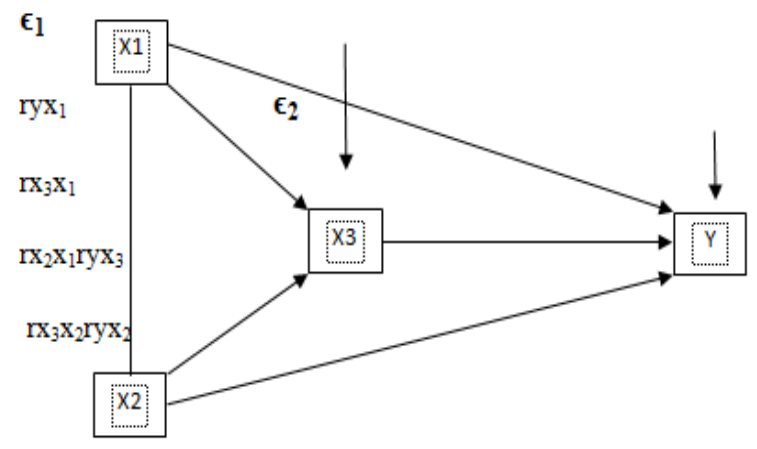

Gambar 3.1 Model Penelitian

Berdasarkan model penelitian di atas, maka kerangka hubungan kausal empiris penelitian ini terdapat persamaan struktural sebagai berikut:

Sub struktur $-1: \mathrm{X} 3=\rho \times 3 \times 1 \mathrm{X}_{1}+\rho \times 3 \times 2 \mathrm{X}_{2}+\varepsilon 1 \ldots . .(1)$

Sub struktur $-2: Y=\rho y x 1 X_{1}+\rho y x 2 X_{2}+\rho y x 3 X_{3}+\varepsilon 2 \ldots$ (2)
Tabel 3.4 Rangkuman Hasil Analisis Koefisien Jalur Sub Struktur-1.

\begin{tabular}{|c|c|c|c|c|c|c|}
\hline $\begin{array}{l}\text { Pergenh } \\
\text { tutr Viriabel }\end{array}$ & $\begin{array}{l}\text { Kuefisiten } \\
\text { Jihr (Bea) }\end{array}$ & $\begin{array}{l}\text { Vilui } \\
\text { the }\end{array}$ & $F_{\text {men }}$ & $\begin{array}{c}\text { Havil } \\
\text { Pengyijin }\end{array}$ & $\mathbb{R}_{0} \mathrm{X}_{\mathrm{H}} \mathrm{X}_{\mathrm{I}}$ & $\mathrm{Al}_{\mathrm{s}} \mathrm{p}_{\mathrm{Z}}$ \\
\hline$X_{t}$ temadep $X_{f}$ & 0935 & 4138 & \multirow{2}{*}{16,477} & Hz ittam & \multirow{2}{*}{0,171} & \multirow{2}{*}{0,029} \\
\hline Xatemadaly $X_{1}$ & 0226 & 3,068 & & Ha trama & & \\
\hline
\end{tabular}

Dapat dijelaskan bahwa pengujian analisis jalur untuk sub struktur-1 signifikan pada 0,05. Dengan demikian, dapat dinyatakan semua jalur berarti. Besarnya koefisien determinan (Rsquare) atau $\mathrm{R}^{2} \mathrm{X}_{3} \mathrm{X}_{1} \mathrm{X}_{2}$ sebesar 0,171 atau $17,1 \%$ yang berarti pengaruh supervisi kepala sekolah dan disiplin kerja terhadap kompetensi guru MAN se-Kota Medan sebesar $17,1 \%$. Sedangkan pengaruh variabel lainnya yaitu $\rho \times 3 \varepsilon 1=1-0,171=0,829$ atau $82,9 \%$. Dengan artian bahwa pengaruh variabel supervisi kepala sekolah dan disiplin kerja guru terhadap kompetensi guru sebesar $17,1 \%$, sedangkan sisanya $82,9 \%$ dipengaruhi oleh variabel lainnya di luar model penelitian.

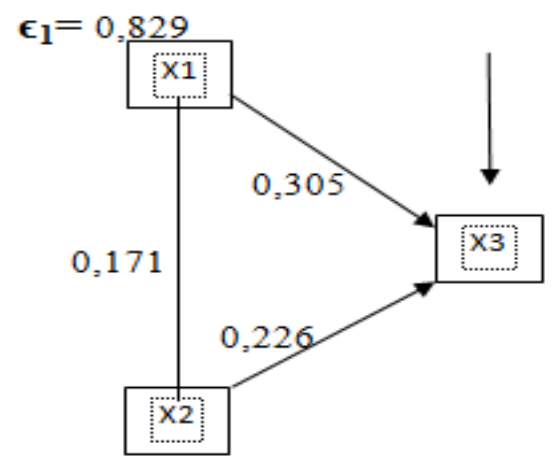

\section{Gambar 3.2 Hubungan Simultan Supervisi Kepala Sekolah Dan Disiplin Kerja Terhadap Kompetensi Guru}

Tabel 3.5 Rangkuman Hasil Analisis Koefisien Jalur Sub Struktur-2.

\begin{tabular}{|c|c|c|c|c|c|c|}
\hline 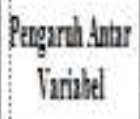 & $\begin{array}{c}\text { Sotivia } \\
\text { Jalur (Btiz) }\end{array}$ & $\begin{array}{l}\text { Thii } \\
\text { the }\end{array}$ & $\mathrm{F}_{\mathrm{ras}}$ & $\begin{array}{c}\text { Bril } \\
\text { Pengujian }\end{array}$ & $\mathrm{R}_{T} \mathrm{H}_{\mathrm{H}}$ & Ph \\
\hline X tetadesp Y & 01186 & 250 & \multirow{3}{*}{$17,0,4$} & Bl detrma & \multirow{3}{*}{0.45} & \multirow{3}{*}{0,775} \\
\hline fytededap I & 0.115 & 2700 & & Br fitrima & & \\
\hline Xytadadey & 0.31! & 1.494 & & Ba dterma & & \\
\hline
\end{tabular}

Dapat dijelaskan bahwa pengujian analisis jalur untuk sub struktur-2 signifikan pada 0,05. Dengan demikian, dapat dinyatakan semua jalur berarti. Besarnya koefisien determinan (Rsquare) atau $\mathrm{R}^{2} \mathrm{yx}_{1} \mathrm{x}_{2} \mathrm{x}_{3}$ sebesar 0,245 atau $24,5 \%$ yang berarti secara simultan supervisi, disiplin kerja dan 
kompetensi berpengaruh terhadap kinerja guru MAN se-Kota Medan sebesar 24,5\%. Sedangkan pengaruh variabel lainnya yaitu $\rho y \varepsilon 2=1-0,245=0,775$ atau $75,5 \%$.

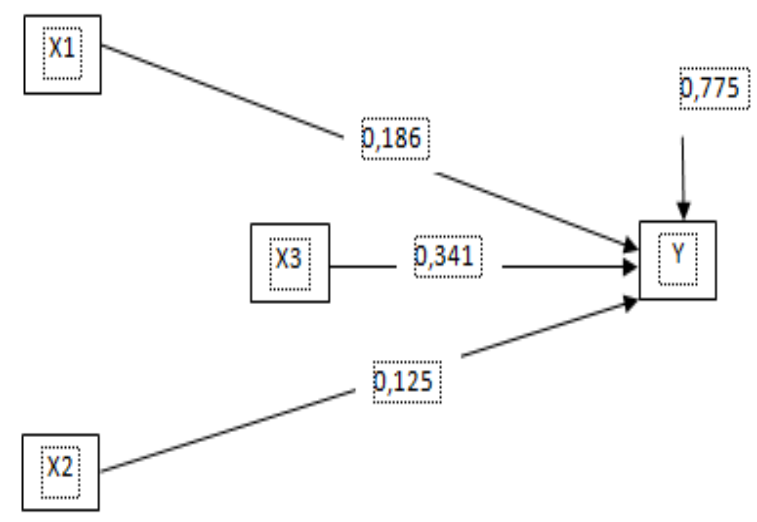

Gambar 3.3 Model Analisis Jalur Supervisi, Disiplin Kerja dan Kompetensi Terhadap Kinerja Guru

Berdasarkan hasil analisis data di atas dapat dijelaskan model temuan penelitian ini sebagai berikut:

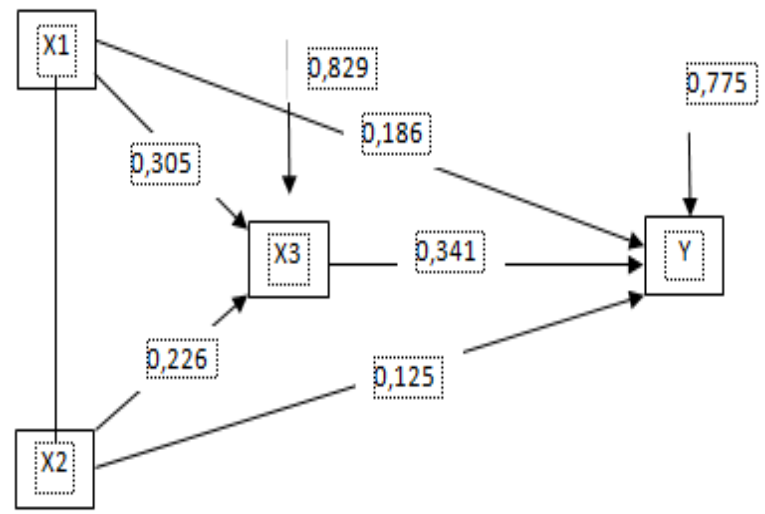

\section{Gambar 3.4 Model Temuan Penelitian}

Berdasarkan model di atas dapat dijelaskan bahwa pengaruh langsung supervisi kepala sekolah terhadap kinerja guru MAN se-Kota Medan sebesar 0,186 . Sedangkan pengaruh tidak langsung supervisi kepala sekolah melalui kompetensi guru terhadap kinerja guru MAN se-Kota Medan sebesar $(0,305 \mathrm{x}$ $0,341)=0,104$. Maka pengaruh total yang diberikan supervisi $\left(\mathrm{X}_{1}\right)$ terhadap kinerja $(\mathrm{Y})$ adalah pengaruh langsung ditambah dengan pengaruh tidak langsung yaitu: $0,305+0,341=0,646$. Berdasarkan perhitungan diatas diketahui bahwa nilai pengaruh tidak langsung $(0,646)$ lebih besar dibanding dengan nilai pengaruh langsung $(0,186)$. Hasil ini menunjukkan secara langsung supervisi $\left(\mathrm{X}_{1}\right)$ melalui disiplin $\left(\mathrm{X}_{3}\right)$ mempunyai pengaruh signifikan terhadap kinerja guru (Y).
Pengaruh langsung disiplin kerja terhadap kinerjaguru MAN se-Kota Medan sebesar 0,125, sedangkan pengaruh tidak langsung disiplin kerja terhadap kinerja guru melalui kompetensi guru sebesar $(0,226 \times 0,341)=0,077$. Maka pengaruh total yang diberikan kompetensi $\left(\mathrm{X}_{2}\right)$ terhadap kinerja $(\mathrm{Y})$ adalah pengaruh langsung ditambah pengaruh tidak langsung : $0,226+0,341=0,567$. Berdasarkan perhitungan diatas diketahui bahwa nilai pengaruh tidak langsung $(0,567)$ lebih besar dari nilai pengaruh langsung $(0,125)$. Berdasarkan model temuan di atas dapat dikatakan bahwa supervisi kepala sekolah, disiplin kerja dan kompetensi guru merupakan variabel-variabel prediktor bagi peningkatan kinerja guru dan signifikan mempengaruhi kinerja guru MAN se-Kota Medan.

Berdasarkan temuan-temuan penelitian ini, secara umum didapat sebagai berikut

1. Supervisi berpengaruh langsung terhadap disiplin guru

Berdasarkan temuan penelitianmenunjukkan ada pengaruh langsung supervisi kepala sekolah terhadap disiplin guru yakni sebesar 0,305. Dapat dijelaskan bahwa ada pengaruh langsung supervisi terhadap disiplinguru MAN se-Kota Medan.Pelaksanaan supervisi yang dilakukan kepala sekolah meliputi penilaian yang dilaksanakan langsung kepala sekolah kepada guru dalam proses pembelajaran yakni (1) perencanaan supervisi, (2) pelaksanaan supervisi, dan (3) tindak lanjut supervisi.

2. Supervisi berpengaruh langsung terhadap kinerja guru

Hasil penelitian ini menunjukkan bahwa pengaruh supervisi secara langsung terhadap kinerja guru sebesar 0,186. Temuan ini menggambarkan bahwa supervisi sangat berpengaruh terhadap peningkatan kinerja guru MAN se-Kota Medan. Supervisi berhubungan langsung dengan kinerja guru, dan berkaitan erat dengan siswa dalam proses belajar.

3. Disiplin kerja berpengaruh terhadap kinerja guru Temuan penelitian ini menunjukkan bahwa disiplin kerja memiliki pengaruh langsung terhadap kinerja guru MAN se-Kota Medan yakni 0,341 atau $34,1 \%$. Berdasarkan temuan ini untuk mendukung lancarnya pelaksanaan pekerjaan, maka diperlukan adanya disiplin kerja.

4. Kompetensi berpengaruh terhadap disiplinkerja guru

Hasil penelitian ini menunjukkan terdapat pengaruh kompetensisecara langsung terhadapdisiplin kerja sebesar 0,226. Hal ini menggambarkan bahwa kompetensi mempengaruhi kompetensi disiplin kerja guru. Semakin tinggi kompetensi seseorang maka semakin tinggi pula disiplin kerjanya. 
5. Kompetensi guru berpengaruh terhadap kinerja guru

Hasil temuan ini menunjukkan bahwa pengaruh kompetensi guru terhadap kinerja guru yakni 0,125 atau sebesar $12,5 \%$. Ini menunjukkan bahwa kompetensi guru sangat menentukan kinerja guru tersebut.

\section{KESIMPULAN DAN SARAN}

\section{Kesimpulan}

Berdasarkan hasil penelitian ini dapat disimpulkan sebagai berikut

1. Terdapat pengaruh langsung dan positif supervisi terhadap disiplin guru yakni sebesar 0,305. Dan terdapat pengaruh langsung disiplin terhadap kinerja sebesar 0,341. Dapat dijelaskan bahwa ada pengaruh langsung supervisi terhadap kinerja guru MAN Medan.

2. Terdapat pengaruh langsung kompetensi terhadap disiplin sebesar 0,226. Dan Terdapat pengaruh langsung dan posistif disiplin terhadap kinerja guru sebesar 0,341 Dapat dijelaskan bahwa ada pengaruh langsung kompetensi terhadap kinerja guru MAN Medan.

3. Secara simultan pengaruh supervisi kepala sekolah dan disiplin kerja terhadap kompetensi guru MAN Medan sebesar 17,1\%. Sedangkan pengaruh variabel lainnya $82,9 \%$. Dengan artian bahwa pengaruh variabel supervisi kepala sekolah dan disiplin kerja guru terhadap kompetensi guru sebesar $17,1 \%$, sedangkan sisanya $82,9 \%$ dipengaruhi oleh variabel lainnya di luar model penelitian.

4. Terdapat pengaruh langsung dan postif supervisi terhadap kinerja guru sebesar 0,186 . Temuan ini menggambarkan bahwa supervisi sangat berpengaruh terhadap peningkatan kinerja guru MAN Medan.

5. Terdapat pengaruh langsung dan postif disiplin kerja terhadap kinerja guru yakni 0,125. Temuan ini menggambarkan bahwa disiplin kerja sangat berpengaruh terhadap kompetensi guru MAN Medan.

6. Terdapat pengaruh langsung dan positif kompetensi guru terhadap kinerja guru yakni 0,341.Temuan ini menggambarkan bahwa kompetensi kerja sangat berpengaruh terhadap kinerja guru MAN Medan.

7. Secara simultan supervisi, disiplin kerja dan kompetensi berpengaruh terhadap kinerja guru MAN Medan sebesar 24,5\%. Sedangkan sisanya $75,5 \%$ dipengaruhi oleh variabel lainnya di luar model penelitian.

\section{Saran}

berikut:

Adapun saran-saran yang diajukan sebagai

1. Untuk meningkatkan kinerja guru MAN Medan, agar kepala sekolah melaksanakan supervisi secara terencana dan berkelanjutan. Mengingat supervisi merupakan tugas yang harus dilakukan kepala sekolah. Selain supervisi yang dilakukan kepala sekolah dilakukan sebagai pembinaan kepada guru yang berupa bimbingan atau tuntunan kearah perbaikan situasi pendidikan di sekolah dan peningkatan mutu mengajar guru.

2. Dalam upaya guru meningkatkan kinerja di sekolah, guru harus memiliki kompetensi yang mendukung. Dalam pelaksanaan tugas guru, profesi guru dituntut memiliki kecakapan yang memenuhi persyaratan yang telah dibakukan oleh pihak yang berwewenang (standar kompetensi guru). Oleh karena itu guru harus meningkatkan pengetahuan, ketrampilan, sikap dan nilai-nilai dalam melaksanakan tugas-tugas sesuai dengan pekerjaan tertentu sebagaimana Peraturan Pemerintah Nomor 19 Tahun 2005 tentang Standar Nasional Pendidikan, guru harus memiliki kompetensi pedagogik, kepribadian, profesional, dan sosial

3. Oleh karena disiplin kerja berpengaruh terhadap kinerja guru, maka guru harus taat dan patuh terhadap peraturan kerja. Untuk itu, guru perlu meningkatkan kesadaran dan kesediaan menaati semua peraturan sekolah dan norma-norma sosial yang berlaku di sekolah. Dengan disiplin kerja yang baik pada diri guru, maka akan semakin tinggi prestasi kerja yang akan dicapai. Disamping itu, pengelolaan dan pengendalian terhadap disiplin kerja di sekolah harus dilakukan oleh manajemen sekolah secara baik, agar para guru dapat bekerja sesuai dengan ketentuan yang berlaku dan kinerja mereka sesuai dengan yang diharapkan dan dapat mencapai tujuan yang ditetapkan.

4. Secara psikologis wanita lebih dapat memahami karakter peserta didik yang mempunyai latar belakang yang berbeda. Oleh karena itu memang sangat dibutuhkan persentase guru wanita lebih dominan daripada laki-laki

5. Untuk regenerasi guru yang umurnya diatas 51 tahun yang akan pensiun dibutuhkan rekruitment guru baru dan ternyata kebutuhan guru-guru muda sudah terjawab dengan adanya CPNS baru yang telah ditempatkan di MAN seKota Medan.

\section{DAFTAR PUSTAKA}

[1] Fathurrohim, Hadi, Pengaruh Pelaksanaan Supervisi Pendidikan Terhadap Kinerja Guru Di Sekolah Dasar, Jurnal Pendidikan Guru Sekolah Dasar, Edisi 33 Tahun Ke-5(2016): 114-120

[2] S, Tatang, 2016, Supervisi Pendidikan, CV Pustaka Setia, Bandung

[3] Hardiana, T., Parijo, \&Utomo, B. B, 2013, Pengaruh kompetensi pedagogik guru terhadap hasil belajar siswa pada mata pelajaran IPS 
kelas X di SMK Muhammadiyah Pontianak, Jurnal Pendidikan dan Pembelajaran, Vol 2(9).

[4] Barnawidan, Arifin, 2012, Kinerja Guru Profesional, Ar-Ruzz Media, Yogyakarta

[5] Mulyasa, H.E, 2014, Guru dalam Implementasi Kurikulum 2013, PT Remaja Rosdakarya, Bandung

[6] Suhardan, Dadang, 2010, Supervise Profesional, Alfabeta, Bandung

[7] Himpunan Peraturan Menteri Pendidikan Nasional (Keputusan Menteri Pendidikan Nasional Tahun 2003) cet 2, 2007, SinarGrafika, Jakarta

[8] Mulyasa, H.E, 2007, Menjadi Kepala Sekolah Profesional, PT Remaja Rosdakarya, Bandung

[9] Majid, Abdul. 2011. Perencanaan Pembelajaran, PT. Remaja Rosdakarya, Bandung

[10] Usman, Moh.Uzer, 2002, Menjadi Guru Profesional, Remaja Rosdakarya, Bandung

[11] Imron, Ali, 2002, Manajemen Peserta Didik Berbasis Sekolah, Bumi Aksara, Jakarta

[12] A.M., Sardiman, 2008, Interaksi Dan Motivasi Belajar Dan Mengajar, Raja Grafindo Persada, Jakarta 